\title{
VERBALIZATION OF POLITENESS IN MODERN ENGLISH
}

\section{Fabian M. P.}

\section{INTRODUCTION}

The ability of human beings to talk - to use language in order to communicate with each other - is so universal and seems so natural that most of us do not think much about it. We take it for granted that it is normal for human beings to talk, the same as to eat, sleep or walk. Though it is true that every normal human being is able to use language, it is misleading to compare this with his/her ability to eat, sleep, or walk. All of these abilities are passed on to us by genetic transmission: we inherit them from our parents, but in the case of language it is only the ability to talk and understand that is inherited genetically. The language or languages we speak are passed on to us by cultural transmission, i.e. a language is something that we learn and are taught, not something that we know by instinct. By the statement that language is culturally transmitted we mean that it is part of the whole complex and shared behaviour which is called culture. The latter includes a shared background (for example, national, ethnic, religious) resulting from a common language and communication style, customs, beliefs, attitudes, and values ${ }^{1}$.

Culture, unlike language, is not composed of fixed rules that apply to all members of one culture. In its broad sense, culture has two major aspects: the history of civilization and a sociological component by which we mean the attitudes, customs, traditions, daily activities of people, their ways of thinking, their values, etc. Moreover, cultural patterns, customs and ways of life are generally reflected in the language because language and culture are mutually interdependent and mutually influential. Furthermore, without a strong power - base, whether political, military or economic, no language can make progress as an international medium of communication. Language has no independent existence, living in some

\footnotetext{
${ }^{1}$ Levine D.R., Adelman M.B. Beyond Language. Cross-Cultural Communication. New Jersey: Prentice Hall, 1993. P. 2. 
sort of mystical space apart from the people who speak it. Language exists only in the brains and mouths and ears and hands and eyes of its users. When they succeed, on the international stage, their language succeeds. When they fail, their language fails ${ }^{2}$.

Human language is a universal and recognizable part of human behaviour and of the human faculties, perhaps one of the most essential to human life, and one of the most far - reaching of human capabilities in relation to the whole span of mankind's achievements. Language in all its forms and manifestations constitutes the field of the linguist. He seeks a scientific understanding of the place of language in human life, and of the ways in which it is organized to fulfil the needs it serves and the functions it performs ${ }^{3}$.

Etiquette lexis functions and develops in close relationship with the society. Norms of etiquette reveal the state of the society's cultural development, and following them contributes to its progress. This is a dialectical unity and connection between etiquette and society.

\section{Language and culture relationship}

Meaning in language involves a set of multiple and various relations holding between the utterance and its parts and the relevant features and components of the environment, both cultural and physical, and forming part of the more extensive system of interpersonal relations involved in the existence of human societies. The term culture is widely used in a number of different ways. It is taken from the technical vocabulary of anthropology, wherein it encompasses the entire way of life of community members in so far as it is conditioned by that membership. Culture refers to the patterns of human activity and the symbols that give significance to these activities. It manifests itself in terms of the art, literature, costumes, customs, language, religion and religious rituals. The people and their patterns of life make up the culture of a region. Cultures vary in the

${ }^{2}$ Crystal D. English as a global language. Cambridge: Cambridge University Press, 1997. P. 5.

${ }^{3}$ Robins R.H. General Linguistics. An Introductory Survey. London: Longmans, 1967. P. 2-3. 
different parts of the world. They differ across boundaries and the diversity of cultures results in the diversity of people around the world.

Culture is the centre of a society, and without it no society can exist. It is a heritage transmitted from one generation to another; it includes all the ways and behaviours of social life; no culture belongs to an individual, and it does not exist in isolation because it is a product of society, and develops through social interaction. Modern times have witnessed an intermix of cultures. The latter are blended together giving rise to shared cultures. By culture we mean: 1) the arts and other manifestations of human intellectual achievement regarded collectively; 2) the ideas, customs, and social behaviour of a particular people or society. Wikipedia defines culture as an umbrella term which encompasses the social behaviour and norms found in human societies, as well as the knowledge, beliefs, arts, laws, customs, capabilities and habits of the individuals in these groups. It has the following characteristics:

- culture is learned and acquired;

- culture is shared and transmitted;

- culture is social;

- culture is ideational;

- culture gratifies human needs;

- culture is adaptive;

- culture tends toward integration;

- culture is cumulative.

The word "culture" means language, communication, courtesies, rituals, roles, customs, relationships, practices, expected behaviours, values, thoughts and manners of interacting. Furthermore, culture includes medical care, religion, food, folk art, celebrations, jokes, manners, clothes and dressing, working schedules, child-rearing methods. The relationship between language and culture is deeply rooted. Language is used to maintain and convey culture and cultural ties. Learning about culture is just as important as learning the languages. To fully appreciate a language, we need to understand the culture of the people who speak it. Language is the method of human communication, either in written or a spoken form whereas, culture is the idea, values and beliefs we have in our society. 
Communication or language is a mechanism for channeling culture and cultural bonds that reflects and reproduces culture. Different ideas are born form different languages within the same culture. Culture is something influenced and impacted by the language whereas, language is formed by the culture of a society. Similarly, language is not only an expression or a means of communication, but a component of a culture that makes it unique and specific. The implications of the link between language and culture is very important to understand the values, ideologies and history. We must be able to understand the cultural background of language to truly learn the language.

Language and culture are intimately related. They change together. We pass on our culture through our language, and we are guided by our language to determine our culture. Our culture and our language to some extent determine possible changes in both. Language and culture are systems that reinforce each other and exclude something of which they cannot conceive because their language does not allow them to think of those things or of which their culture does not contain.

The exact nature of the relationship between language and culture has fascinated, and continues to fascinate, people from a wide variety of backgrounds. One long-standing claim concerning the problem in question is that the structure of a language determines the way in which speakers of that language view the world. A somewhat weaker version is that the structure does not determine the worldview but is still extremely influential in predisposing speakers of a language toward adopting a particular worldview. The opposite claim would be that the culture of people finds its reflection in the language they employ, i.e. they value certain things and do them in a certain way, so they use their language to reflect what they value and what they do. In this view, cultural requirements do not determine the structure of a language, but they influence the ways a language is used. Finally, there also exists a viewpoint based on the assumption that there is little or no relationship between language and culture. Acknowledging close relationship between language and culture, we consider that any overestimation/underestimation either of a language or a culture can cause misunderstandings and lead to inadequate conclusions. 
Language learning should be tied up with culture learning, but it does not mean that one cannot exist without the other. With language learning, we do not just learn about the language: we learn to speak it. With culture learning, we do not just learn about a culture: we learn how to cope with cultural differences, and we learn how to effectively communicate with people in another culture. Learning to communicate comfortably with people is as important as learning the rules of a language. Moreover, language learning and culture learning go together and may take a long time. Much of human experience - both individual and corporate - is mediated through communication, linguistic as well as non-linguistic. A good way to become aware of interaction in another culture is to think about how we interact with people in our own language and culture. This helps recognize both differences and similarities between our and another cultures. Language itself is the most remarkable tool that man has invented, and is the one that makes all the others possible. Language, in fact, is the great machine tool which makes human culture possible ${ }^{4}$.

In the language development the social nature of lexical units is revealed in a variety of forms. Moreover, the ongoing processes of change affect all aspects of English structure. As always, the most noticeable sign of change is in vocabulary, which reflects the multiple social, scientific, technological, and economic developments. During the later decades of the XVII century the proliferation of tea terminology began to enter English vocabulary. As Crystal David puts it, the first recorded reference to the word is 1655. In 1661, tea-taking was introduced into the Restoration Court by Queen Catherine, the Portuguese wife of Charles II, and it immediately became the fashion. At high social levels, it became a formal ritual accompanied by an elegant apparatus of silver spoons, pots, stands, tongs, and caddies, and an occasion for polite conversation. But the innovation was taken up by other levels of society, too. As its price fell, everyone adopted the habit, upstairs and downstairs alike, taking tea usually twice a day ${ }^{5}$. In an era where much emphasis is laid on social hierarchy, degrees in society become very important. It is the time when a

\footnotetext{
${ }^{4}$ Barber C.L. The Story of Language. London: Pan Books Ltd., 1972. P. 1.

${ }^{5}$ Crystal D. The Stories of English. Woodstock \& New York: The Overlook Press, 2004. P. 370.
} 
special attention is paid to codes of appearance, hair-style, all aspects of behaviour, and especially language. The words like polish, refinement, manners, politeness, elegant, respect, courtesy, tact, compliment, attention, civility and many others characterize both everyday lives of people and various ways as well as forms of performing their everyday communications.

It is possible to treat politeness as a fixed concept, as in the idea of "polite social behavior", or etiquette, within a culture. It is also possible to specify a number of different general principles for being polite in social interaction within a particular culture. Some of these might include being tactful, generous, modest, and sympathetic toward others ${ }^{6}$.

Good manners, polite behaviour and reverential attitude, respect towards people irrespective of their age, sex, cultural and educational background are highly evaluated in the society. In other words, all the abovementioned qualities and characteristics refer to etiquette which denotes: 1. a. The prescribed ceremonial of a court; the formalities required by usage in diplomatic intercourse. $b$. The order of procedure established by custom in the army or navy (esp. with reference to promotion), in parliament, etc. c. The conventional rules of personal behaviour observed in the intercourse of polite society; the ceremonial observances prescribed by such rules. $d$. The unwritten code of honour by which members of certain professions (esp. the medical and legal) are prohibited from doing certain things deemed likely to injure the interests of their brethren, or to lower the dignity of the profession. 2. A rule of etiquette; an observance prescribed by etiquette. 3. In the primary Fr. sense: a label ${ }^{7}$. Etiquette in Webster's New Encyclopedic Dictionary is explained as: the body of rules governing the way in which people behave socially, ceremonially, or in public life [French étiquette, literally, "ticket"]. Origin. The primary meaning of French etiquette is "ticket, label attached to something for description or identification". It was once the practice in royal palaces of France to post notices that set down the proper forms to be observed at court. Such notices were called étiquettes. The word came to be used for

\footnotetext{
${ }^{6}$ Yule G. Pragmatics. Oxford: Oxford University Press, 1996. P. 60.

${ }^{7}$ The Compact Edition of the Oxford English Dictionary in 2 volumes. Complete Text Reproduced Micrographically. Oxford: Oxford University Press, 1971.
} 
the court ceremonial itself as well as the document that described it. It was this sense of French étiquette that English borrowed ${ }^{8}$. Etiquette is also defined as the set of rules or customs which control accepted behavior in particular social groups or social situations ${ }^{9}$. Longman Dictionary of English Language and Culture explains the meaning of the word in question the following way: the formal rules of proper (social) behaviour: medical/professional etiquette. Cultural Note. In Britain, the rules of social behaviour are not as severe as they were in the past, but there are still many rules about formal behaviour in upper-class society. People who move up in society sometimes look at etiquette books to learn how they are expected to behave ${ }^{10}$. Despite minor differences, the abovementioned dictionaries as well as other theoretical sources highlight the essence of etiquette as a set of rules for behaving correctly in social situations, and also rules about behaviour for people in a particular profession.

\section{Lexical semantic analysis of the nouns denoting politeness in modern English}

Majority of words denoting politeness in modern English are polysemantic. They make up a system of elements which reveals various language means of expressing the notion of politeness. All the meanings of the nouns in question are interconnected and interrelated. To collect and analyze them, the methodology of formalized analysis of lexical semantics is used ${ }^{11}$. To choose the material of our research and study the system and structural peculiarities of its lexical semantics, a formal, pure linguistic criterion is introduced - belonging of the words to a definite part of speech. In our study it is the noun. It means that the lexical units refer to a definite class in English whatever semantic functions other members of that class may fulfil, and the label noun is applied to all the words assigned to this

\footnotetext{
${ }^{8}$ Webster's New Encyclopedic Dictionary. Cologne, Germany:Könemann, 1993. P. 344.

${ }^{9}$ Cambridge International Dictionary of English. Cambridge:Cambridge University Press, 1995. P. 470.

${ }^{10}$ Longman Dictionary of English Language and Culture. England: Longman Group UK Limited, 1992. P. 436.

${ }^{11}$ Фабіан М.П. Семантика мовного етикету: новий підхід до ії вивчення // Сучасні дослідження з іноземної філології, випуск 12. Ужгород : ПП “Аутдор -Шарк”, 2014. C. 7-13.
} 
class. This means that some words in many languages, especially words in frequent use, have to be classified under more than one head ${ }^{12}$. Our word class is open in membership, i.e. its membership is unlimited, varying from time to time and between one speaker or another. The language material under analysis is selected from the explanatory dictionary of English ${ }^{13}$ owing to the way the lexical units are presented in it. In this case we mean that each word in the explanatory dictionary appears as a linguistic fact possessing a certain form and content. Its form is treated as a manifold phenomenon, owing to which the lexical meaning can be revealed in its entirety. The correlation between form and content in modern linguistics is best revealed in the dictionaries: the completest the dictionary, the most detailed this correlation description seems to be. The explanatory dictionary helps make the analysis of the words by linguistic means. Furthermore, explanatory dictionaries provide an exhaustive information concerning language units. Each definition of the word in the dictionary entry presents one of the meanings of this word.

Lexicographical representation of any separate meaning has a complex inner structure. For this reason, in every definition of the nouns denoting politeness we look for the properties and other characteristics which correspond to elementary notions. In the process of our linguistic analysis, the binomial feature of the noun's semantic definition should be taken into consideration: the left part is a word or phrase which needs to be defined, and the right part contains a word, phrases, often lines of phrases to define the meaning of a headword. Moreover, these components reflect one and the same class of subjects, but along with the relations of equality in the semantic definition, there also exit the relations of inequality ${ }^{14}$.

The lexis under study in modern English is characterized by two interconnected facets: the system of nouns as signs to describe their meanings and the system of semantic shades of meaning attached to the nouns. In this respect, each semantic definition to this or that extent fixes

\footnotetext{
${ }^{12}$ Robins R.H. General Linguistics. An Introductory Survey. London:Longmans, 1964. P. 229.

${ }^{13}$ The Oxford English Dictionary: In 12 volumes. London: Oxford University Press, 1961.

${ }^{14}$ Арбатский Д.И. Семантические определения (основные проблемы толкования значений слов): дис. ... докт. филол. наук: 10.02.01. Ижевск, 1981. С. 31.
} 
these two facets. While analyzing dictionary definitions to describe the meanings of the nouns denoting politeness, we stick to the point that the dictionary definition is a metalanguage category which is realized in one and two component forms. By the first the definition consisting only of the nucleus is meant, whereas the second means that the definition is composed of the nucleus and its synonymic equivalents, owing to which the broadening of semantic range of the lexical unit takes place, because they help the latter to enter different lexical microsystems. For the allround study of the words' semantics, of great importance is the way the meanings of words are interpreted by means of other words' meanings in the same dictionary. Not always the dictionary definition suggests an exact equivalent of the necessary word. If the word is used in its figurative meaning, it is to be studied the same way as a main vocabulary one. For the most adequate description of lexical units, the words are used which exactly correspond to the notion under study. We name such words as dominants of the synonymic lines. Not all the elements of the lines become dominants: semantics of the nouns is not limited by the variation of one narrow notion; they also contain other content characteristics. To analyze our English language material, the dominants' meanings are decomposed into components.

It explains the fact why in the process of studying the relationships between the nouns denoting politeness as well as their places and roles, the explanatory dictionary of English serves as the main source of our language material. As a result, we obtained a group of nouns, semantics of which describes various ways of expressing politeness which is closely connected with etiquette, and, to be more exact, makes a part of the latter.

On the whole, Crystal D. compares words with children: we need to know how to look after them and when to let them look after themselves; when to be proud of them, and when to be worried about them. To do all that, we need to find out as much as we can about them. We need to know how words change their meanings and uses, and why. We need to understand the communicative properties of words, so that we can exploit them to our advantage. Above all, we need to be able to describe, 
comprehensively and objectively, the universe of words, and the way people live in it. In short, we need to become lexicologists ${ }^{15}$.

Before making lexical semantic analysis of the nouns in modern English, we have in short to introduce the notion of politeness, and then disclose its relations with other words in the system of the language.

The central notion of etiquette is politeness which presupposes polished manners, courtesy, mental or intellectual culture: polish, refinement, elegance, good taste, deference, tact, and the like. A social historian, Vickery A., writes about the significance of politeness: "Politeness in the eighteenth century meant much more than mere etiquette, and minding your ps and qs. It was an all-embracing philosophy of life, and a model for a harmonious society. It promoted openness and accessibility in social behavior, but at the same time set strict standards of decorum for merchants and manufacturers to live up to. Politeness demanded that people should make themselves agreeable to others, to give pleasure as well as take it. Indeed the social lubrication which politeness offered was one of its great attractions, because it offered a way for very different sorts of people to get along without violence, and helped heal the wounds of civil war. Politeness was an intellectual response to the uncompromising religious fanaticism of the civil war years, and the political hatreds which lingered afterwards"

Politeness stands in line with manners and morals. The latter are never neutral. Their usefulness to men and women lies in this fact for implicit in manners and morals are attitudinal appraisals. Attitudes have their origins in what is termed general or encyclopaedic knowledge of the world and how this knowledge is viewed in terms of the cultural values of a community ${ }^{17}$. Verbalization of politeness in its various aspects in modern English is represented by the nouns manners, respect, courtesy, culture, elegance, grace, attention, ceremony, tact, compliment, civility and civilities.

\footnotetext{
${ }^{15}$ Crystal D. Words. Words. Words. New York: Oxford University Press, 2006. P. 6.

${ }^{16}$ Vickery A. In Pursuit of Pleasure. Milton Keynes: Open University Press, 2001. P. 156.

${ }^{17}$ Chitra F. Idioms and Idiomaticity. New York: Oxford University Press, 1996. P. 139.
} 
The Oxford English Dictionary defines the lexical unit respect as: I. In phrases (usually) without article. II. An aspect of a thing, a relative property or quality, a relationship of one person or thing to another; reference to some thing or person, regard, consideration. III. Appearance, aspect; discrimination, partiality, or favour in regard of persons or things. Heed, care, attention. IV. Deferential regard or esteem felt or shown towards a person or thing. The condition or state of being esteemed or honoured. Rank, standing, station in life. pl. Deferential or courteous attentions; actions expressive of respect for a person; politenesses, courtesies. Deferential salutations. In complimentary formula, usually conveying a message expressive of regard or esteem. To pay one's respects, to show polite attention to a person by presenting oneself or by making a call.

The lexical unit culture denotes: 1. Worship; reverential homage. 2. The action or practice of cultivating the soil; tillage, husbandry. b. Cultivated condition. c. A piece of tilled land; a cultivated field. 3. The cultivating or rearing of a plant or crop. $b$. The rearing or raising of certain animals, such as fish, oysters, bees, etc., or of natural products such as silk. c. The artificial development of microscopic organisms, esp. bacteria, in specially prepared media; the product of such culture; a growth or crop of artificially developed bacteria, etc. d. The training of the human body. 4. The cultivating or development (of the mind, faculties, manners, etc.), improvement or refinement by education and training. 5. The training, development, and refinement of mind, tastes, and manners; the condition of being thus trained and refined; the intellectual side of civilization. b. (with a and pl.) A particular form or type of intellectual development. 6. The prosecution with special attention or study of any subject or pursuit.

The noun manners, in its turn, means: a) polite ways of behaving in social situations, and b) the customs of a particular group of people. Attention also belongs to the group of words under study. It is characterized by broad semantics, because its meanings show various ways of their implications: 1. The action, fact, or state of attending or giving heed; earnest direction of the mind, consideration, or regard; esp. in phr. to give or pay attention. The mental power or faculty of attending; esp. with 
attract, call, draw, arrest, fix, etc. 2. Practical consideration, observant care, notice. 3. The action of attending to the comfort and pleasure of others; ceremonious politeness, courtesy. 4. A matter of attention, a consideration. 5. A cautionary word used as a preparative to any particular exercise or manoeuvre. Close to the word in question stands the noun tact which describes the ability to be polite and careful about what you say or do so that you do not upset or embarrass other people.

In the process of our language material analysis, it becomes evident that the lexical units as the components of the system and structure of English are described in the dictionary with the help of diversiform repetitions of one and the same properties to a lesser or greater extent. This repetition forms a variety of lexical semantics' structural organization continuity. The latter is represented by definitions which, if compared, show that the lexical meanings of the nouns denoting politeness in English come open according to the principle of explaining one word through the second, the second through the third, and so on. As a result, in defining the semantics of the word in its direct connection with the other or other lexical units, we establish, by comparing their semantic structures, not only the presence (absence) of common semantic components, but also the degree of their manifestation. This chain correlation constitutes the semantic regularity of politeness lexis formation.

The quantitative growth of the lexical units under study in the dictionary of modern English occurs against the background of qualitative shifts throughout the vocabulary. It is displayed in the rise of the words' abilities to more exactly express thoughts and emotions of people living in the definite society. Moreover, the research of politeness lexis is directly dependent on the study of the person's inner world which includes imagination, memory, dreams, emotions, evaluation, etc. The process of human cognition always contains the element of evaluation because a man in perceiving the surrounding reality does not remain a passive observer, but expresses his interest in it. The latter inevitably leads to the evaluative classification of the environment and oneself. Evaluation is necessarily present when there is a contact between the subject and the objective world $^{18}$.

${ }^{18}$ Приходько Г.І. Оцінка і комунікація. Вінниця: Нова Книга, 2013. С. 22. 
Evaluative aspect plays an important role in the interaction of a man with the world. In the process of human cognition, upbringing, education, everyday life of a person, his/her character, tastes, outlook produce a certain value system in the individual, based on which he/she gives assessment of the whole world. Evaluation belongs to the number of human categories. It is set by physical and psychic nature of man, his/her being and feeling, it sets thinking and activity, his/her perception of arts ${ }^{19}$. The group of nouns denoting politeness describes various ways and means of expressing evaluation. For example, the lexical unit compliment possesses the following characteristics of showing formal respects: 1. A ceremonial act or expression as a tribute of courtesy, "usually understood to mean less than it declares", now, esp. a neatly - turned remark addressed to any one, implying or involving praise; but, also applied to a polite expression of praise or recommendation in speaking of a person, or to any act taken as equivalent thereto. b. (without a or pl.) Complimentary language; polite expression of praise or flattery. 2. Usually in pl. Formal respects, remembrances, greetings; esp. in phrases. 3. A complimentary gift, a present, gratuity.

The lexical unit grace expresses: 1. A smooth controlled way of moving that is attractive to look at, esp. because it seems natural and relaxed. 2. a) polite and pleasant behaviour; b) graces - the skills needed to behave in a way that is considered polite and socially acceptable: social graces. 3. More time that is added to the period you are allowed for finishing a piece of work, paying a debt, etc. 4. God's kindness shown to people because he loves them. 5. A prayer thanking God, said before a meal. 6. The state of someone's soul when it has been freed from evil, according to Christian belief. Politeness is concerned not only with refined manners, but also courteous behaviour and formal acts expressive of deference or respect. Such meanings explain semantics of the nouns courtesy, ceremony and elegance. The words under analysis in the dictionary of English possess the following characteristics: courtesy 1. Courteous behaviour; courtly elegance and politeness of manners;

${ }^{19}$ Приходько Г.І. Категорія оцінки в контексті зміни лінгвістичних парадигм. Запоріжжя:ЗНУ, 2015. С. 34. 
graceful politeness or considerateness in intercourse with others. 2. As a quality: courteous disposition, courteousness; also nobleness, generosity, benevolence, goodness. 3. Courteous title: a title of no legal validity given by social custom or courtesy; esp. applied to the territorial titles given to the eldest sons of earls and peers of higher rank, the prefix Lord or Lady to the names of the younger sons and the daughters of dukes and marquises, and of Honourable to the children of Viscounts and Barons. 4. Law. A tenure by which a husband, after his wife's death, holds certain kinds of property which she has inherited, the conditions varying with the nature of the property. 5. (pl.) A courteous act or expression. 6. The courteous or ceremonious expression of apology or deprecation. 7. The customary expression of respect by action or gesture, esp. to a superior; the action of inclining, bowing, or lowering the body, usually, in phr. to make or do courtesy. 8. An obeisance. 9. A "mannerly" or moderate quantity. 10. Used like worship, etc. as an ascriptive title.

The next word under analysis is ceremony which means: 1. An outward rite or observance, religious or held sacred; the performance of some solemn act according to prescribed form; a solemnity. b. A rite or observance regarded as merely formal or external; an empty form. Sometimes regarded as symbolic or typical. c. Applied to a thing done in a formal or ceremonious way; a stately formality. 2. A formal act or observance, expressive of deference or respect to superiors in rank, or established by custom in social intercourse; a usage of courtesy, politeness, or civility. 3. (without a or pl.) Formal observances or usages collectively, or as an order of things: a. in reference to matters of religion or state: Performance of rites, ceremonial observance. b. Precise observance of conventional forms of deference or respect; formality, ceremoniousness. c. Ceremonious respect or regard. d. Ceremonial display, pomp, state. 4. An external accessory or symbolical "attribute" of worship, state, or pomp. 5. A portent, omen (drawn from the performance of some rite). 6. Master of the ceremonies: the person who superintends the ceremonies observed in a place of state or on some public occasion. By elegance we mean: 1. Refined grace of form and movement, tastefulness of adornment, refined luxury. 2. Of spoken or written compositions, literary style: Tasteful correctness, harmonious simplicity, 
correctness, harmonious simplicity, in the choice and arrangement of words. 3. A. Of scientific processes, demonstrations, inventions: Neatness, ingenious simplicity, convenience, and affectiveness; so of a prescription, etc. b. Roman Law. 4. a. Correctness of taste. b. Of manners: Refined propriety. 5. Something which is elegant, a particular instance or kind of elegance. Polite behaviour which most people consider normal is called civility. Formal word civilities is something that you say or do in order to be polite. Semantic structures of the nouns expressing politeness are represented as the complexes of interconnected separate meanings within the polysemantic words. Forms, like meanings, are culturally determined. They are also distributed in patterned ways. Forms are relevant when they possess meanings; meanings presuppose forms in order to be of relevance to us, and meaningful forms always occur in patterned distribution ${ }^{20}$.

The use of dictionaries helps define the word's semantic structure as an element of the language's lexical system. Lexical semantic analysis of the words in question shows that within the politeness lexis the word is characterized by the clear - cut hierarchical structure, and the degree of the word's independence in it as well as the sphere of its everyday usage depend upon the character of the relations between the words and the notions they denote, role and place the semantic elements of the words occupy in the system of lexis.

In modern linguistics there exist three viewpoints concerning structural organization of a polysemantic word content:

1) in the structural organization of a polysemantic word's semantics, there is a hierarchy; separate meanings of such words are unequal;

2) the meanings of a polysemantic word are equal, and there is no division into main - secondary, direct - figurative and so on;

3 ) in some cases, the meanings of a polysemantic word are equal, and in others - unequal $^{21}$.

${ }^{20}$ Fabian M. Etiquette Behaviour in the Context of Language and Culture Learning мові// Сучасні дослідження з іноземної філології, випуск 7. Ужгород :ТОВ "ПапірусФ", 2009. С. 6.

${ }^{21}$ Левицкий В.В. Экспериментальные данные к проблеме смысловой структуры слова//Семантическая структура слова. Психолингвистические исследования. Москва: Наука, 1971. С. 153. 
The nouns denoting politeness in modern English form the set which consists of elements. The latter, though united by common properties, still possess certain autonomous peculiarities. In the definitions of polysemantic words one can observe relations which are characteristic of separate lexical units as the elements of the semantic system of English. One of the most important features of system relations in lexical semantics of English is their polyfunctionalism, i.e. between two elements of the language's semantic system, system relations perform the functions of microsystem or macrosystem character. Within the whole lexical system, qualitative different features of the word serve, on the one hand, as the means of lexical meaning formation, and, on the other, as peculiar clips, on the basis of which this lexical meaning of politeness joins the semantic system of English as its element. The presence of such polyfunctional relations characterizes another semantic regularity of politeness lexis formation. Furthermore, the changes in the relations between the words as well as the relations between the meanings within the word, are connected with the changes in the semantic structure of English in general ${ }^{22}$. A detailed and all - round study of each word's specificity helps reveal the peculiarities of its semantics and generalize politeness lexis theory in modern English.

To conclude, within the group of nouns denoting politeness in modern English, the words by means of their meanings are closely interconnected, and thus form the chains of direct as well as indirect ties. Moreover, each element of this group possesses its peculiar individual meanings, owing to which politeness semantics intersects with the concrete semantics of the nouns under study.

\section{CONCLUSIONS}

Contemporary linguistics regards language as a social activity rather than as a means of individual self-expression. Language we speak not only brings human beings into relationship with each other, but it also brings them into relationship with the external world. Language mediates between man and his environment. It is one of the most powerful emblems of social

22 Фабіан М.П. Семантична структура багатозначних лексичних одиниць на позначення етикету в сучасній англійській мові// Сучасні дослідження 3 іноземної філології, випуск 8. Ужгород : ПП “Аутдор -Шарк”, 2010. С. 7. 
behaviour. In the normal transfer of information through language, we use it to send vital social messages about who we are, where we come from, and who we associate with. Consequently, language use symbolically represents fundamental dimensions of both social behaviour and human interaction. There is a correlation between the form and content of a language, and the beliefs, values and needs embedded in the culture of its speakers. Furthermore, the vocabulary of English supplies us with a catalogue of those things which might be important and necessary for the society, an index to the way speakers categorize experience, a record of contacts and cultural borrowings, etc. Moreover, English is much more than external expression and communication of internal thoughts formulated independently of their verbalization. It is a part of culture which refers to all aspects of human life insofar as they are determined or conditioned by membership in a society. Culture covers a very wide area of human life and behaviour, and language is manifestly a part, probably the most important part, of it.

Politeness in modern English is represented by the lexical units, semantics of which contains the indications of polite behaviour, manners, courtesy, polite attention, etc. To such words in our research belong the nouns manners, respect, courtesy, culture, elegance, grace, attention, ceremony, compliment, tact, civility and civilities. Each of them, besides indicating the notion in question, is characterized by its specific meanings which, for instance, denote an aspect of a thing, a relative property or quality, a relationship of one person or thing to another; reference to some thing or person, regard, consideration. Appearance, aspect; discrimination, partiality, or favour in regard of persons or things. Heed, care, attention. Deferential regard or esteem felt or shown towards a person or thing. The condition or state of being esteemed or honoured. Rank, standing, station in life (respect), God's kindness shown to people because he loves them. A prayer thanking God, said before a meal. The state of someone's soul when it has been freed from evil, according to Christian belief (grace), the action, fact, or state of attending or giving heed; earnest direction of the mind, consideration, or regard; esp. in phr. to give or pay attention. The mental power or faculty of attending; esp. with attract, call, draw, arrest, 
fix, etc. Practical consideration, observant care, notice (attention) and many others. All the nouns denoting politeness as well as their meanings form a definite set which possesses a structure. The latter is composed of elements united by common properties, but possessing their individual peculiarities. Both the nouns under study and their meanings, within politeness lexis, establish close relationships with other groups of the lexical system of modern English.

\section{SUMMARY}

The present research deals with the verbalization of politeness in modern English. The author discusses the topical issues of contemporary linguistics concerning the relationship between language and culture, their distinctive features, functions, role and place in both society and people's everyday activities. Much attention is paid to the lexical semantic analysis of the nouns denoting politeness in the vocabulary of English, peculiarities of their system and structural organization, different types of connections between the lexical units which are interrelated though characterized by their specific semantics. Politeness in the present research is represented as the central notion of etiquette which presupposes polished manners, courtesy, mental or intellectual culture: polish, refinement, elegance, good taste, deference, tact, and the like. The quantitative growth of the lexical units under study in the dictionary of modern English occurs against the background of qualitative shifts throughout the vocabulary. It is displayed in the rise of the words' abilities to more exactly express thoughts and emotions of people living in the definite society. Moreover, the research of politeness lexis is directly dependent on the study of the person's inner world which includes imagination, memory, dreams, emotions, evaluation, etc. The paper focuses on the use of dictionaries which help define the word's semantic structure as an element of the language's lexical system. Lexical semantic analysis of the words in our language material shows that within the politeness lexis the word is characterized by the clear - cut hierarchical structure, and the degree of the word's independence in it as well as the sphere of its everyday usage depends upon the character of the relations between the words and the notions they denote, role and place the semantic elements of the words occupy in the system of English lexis. The 
complex study of politeness verbalization in modern English helps recognize both differences and similarities between our and another cultures, enrich our life experience and improve all possible cross-language and cross-cultural communications.

\section{REFERENCES}

1. Barber C.L. The Story of Language. London: Pan Books Ltd., 1972. $294 \mathrm{p}$.

2. Chitra F. Idioms and Idiomaticity. New York: Oxford University Press, 1996. 265 p.

3.Crystal D. English as a global language. Cambridge: Cambridge University Press, 1997. $150 \mathrm{p}$.

4. Crystal D. The Stories of English. Woodstock \& New York: The Overlook Press, 2004. 584 p.

5. Crystal D. Words. Words. Words. New York: Oxford University Press, 2006. 216 p.

6. Fabian M. Etiquette Behaviour in the Context of Language and Culture Learning // Сучасні дослідження 3 іноземної філології, випуск 7. Ужгород :ТОВ “Папірус-Ф”, 2009. С. 5-9.

7.Levine D.R., Adelman M.B. Beyond Language. Cross-Cultural Communication. New Jersey: Prentice Hall, 1993. 286 p.

8. Robins R.H. General Linguistics. An Introductory Survey. London:Longmans, 1964. 391 p.

9.Robins R.H. General Linguistics. An Introductory Survey. London: Longmans, 1967. 398 p.

10. Vickery A. In Pursuit of Pleasure. Milton Keynes: Open University Press, 2001. 269 p.

11. Yule G. Pragmatics. Oxford: Oxford University Press, 1996. 138 p.

12. Арбатский Д.И. Семантические определения (основные проблемы толкования значений слов): дис. ... докт. филол. наук: 10.02.01. Ижевск, 1981. 305 с.

13. Левицкий В.В. Экспериментальные данные к проблеме смысловой структуры слова // Семантическая структура слова. Психолингвистические исследования. Москва: Наука, 1971. С. 151-168. 
14. Приходько Г.І. Оцінка і комунікація. Вінниця: Нова Книга, 2013. $168 \mathrm{c}$.

15. Приходько Г.І. Категорія оцінки в контексті зміни лінгвістичних парадигм. Запоріжжя: ЗНУ, 2015. 172с.

16. Фабіан М.П. Семантична структура багатозначних лексичних одиниць на позначення етикету в сучасній англійській мові // Сучасні дослідження 3 іноземної філології, випуск 8. Ужгород : ПП “Аутдор-Шарк”, 2010. С. 5-11.

17. Фабіан М.П. Семантика мовного етикету: новий підхід до іiі вивчення//Сучасні дослідження 3 іноземної філології, випуск 12. Ужгород : ПП “Аутдор -Шарк”, 2014. С. 7-13.

\section{IEXICOGRAPHICAL SOURCES}

18. Cambridge International Dictionary of English. Cambridge: Cambridge University Press, 1995.

19.The Compact Edition of the Oxford English Dictionary in 2 volumes. Complete Text Reproduced Micrographically. Oxford: Oxford University Press, 1971.

20. Longman Dictionary of English Language and Culture. England: Longman Group UK Limited, 1992.

21. The Oxford English Dictionary: In 12 volumes. London: Oxford University Press, 1961.

22.Webster's New Encyclopedic Dictionary. Cologne, Germany: Könemann, 1993.

\section{Information about the author: \\ Fabian M. P.,}

Doctor of Philological Sciences in General Linguistics, Professor,

Professor at English Philology Department

Uzhhorod National University 14, office 521, Universytetska str., 88000, Uzhhorod, Zakarpattia region, Ukraine 